\title{
The severity of intrahepatic cholestasis of pregnancy can shorten the first stage of labor in multiparous women induced by prostaglandin E2
}

\section{Gebelik intrahepatik kolestazının şiddeti, prostaglandin E2 ile indüklenen multipar kadınlarda doğumun ilk aşamasını kısaltabilir}

\author{
Banuhan Şahin $^{1 *}$ (D), Samettin Çelik ${ }^{2}$ (D), Canan Soyer-Çalışkan ${ }^{2}$ (D), Şafak Hatırnaz ${ }^{3}$ (D), \\ Handan Çelik ${ }^{4}$ \\ ${ }^{1}$ Amasya University Sabuncuoglu Serefeddin Training and Research Hospital, Department of Gynecology and Obstetrics, Amasya, Turkey \\ ${ }^{2}$ Samsun Training and Research Hospital, Department of Gynecology and Obstetrics, Samsun, Turkey \\ ${ }^{3}$ Medicana Samsun International Hospital, Department of Gynecology and Obstetrics, Samsun, Turkey \\ ${ }^{4}$ Ondokuz Mayıs University, Medical School, Department of Gynecology and Obstetrics, Samsun, Turkey \\ * Corresponding author: Banuhan Şahin E-mail: banuhansahin@gmail.com ORCID: 0000-0002-8711-1584 \\ Received: 3 April 2020 Accepted: 30 April 2020
}

\begin{abstract}
Aim: To determine the relationship between increased serum bile acid concentrations and the first stage of labor in multiparous women induced by vaginal prostaglandin E2 (PGE2) with intrahepatic cholestasis of pregnancy (ICP).

Material and Methods: In this retrospective case-control study 283 multiparous women with ICP and 283 healthy multiparous pregnant women were admitted for induction of delivery, were inserted PGE2 (10 mg dinoprostone) vaginally. The groups with mild, moderate and severe ICP were compared with control group in terms of the time from beginning of PGE2 vaginal insertion to active phase of labor, the time from beginning of PGE2 vaginal insertion to complete dilatation of cervix and fetal outcomes.
\end{abstract}

Results: The time from beginning of PGE2 insertion to active phase in the mild, moderate and severe ICP groups were shorter than in the non-ICP group; $3.19 \pm 0.32,7.26 \pm 0.34,8.71 \pm 0.35$ hours, respectively $(p<0.01)$. The time from beginning of PGE2 insertion to complete dilatation of cervix in the groups with mild, moderate and severe ICP were shorter than in non-ICP group; $3.03 \pm 0.45 ; 10.33 \pm 0.62 ; 14.44 \pm 0.53$, respectively $(p<0.01)$. There was no difference between the groups in terms of fetal outcomes except fetal weight and the presence of meconium $(p<0.01)$.

Conclusion: Increased bile acid concentrations in multiparous pregnant women induced by vaginal PGE2 with mild, moderate and severe ICP are associated with shorter duration of cervical ripening and labor induction time to delivery. The study concluded that multiparous women with ICP can deliver faster as the severity of cholestasis increases.

Keywords: bile acid, duration of labor, intrahepatic cholestasis of pregnancy, prostaglandin E2, severity of cholestasis

() 2020 by the authors; licensee MEDITAGEM Ltd., Turkey. This article is an open access article distributed under the terms and conditions of the Creative Commons Attribution License (http://creativecommons.org/licenses/by/4.0/). 


\section{öz}

Amaç: Vajinal prostaglandin E2 (PGE2) ile indüklenen multipar kadınlarda gebeliğin intrahepatik kolestazına (ICP) bağlı artan serum safra asit konsantrasyonları ile doğumun ilk evresi arasındaki ilişkiyi belirlemek.

Gereç ve Yöntemler: Bu retrospektif vaka-kontrol çalışmasında 283 ICP'li ve 283 sağlıklı multipar gebe doğum indüksiyonu için kabul edildi, vajinal olarak PGE2 (10 mg dinoproston) yerleştirildi. Hafif, orta ve şiddetli ICP'li gruplar, PGE2'nin vajinal yerleştirilmesinin başlangıcından doğumun aktif evresine kadar geçen süreler, PGE2'nin vajinal yerleştirilmesinin başlangıcından serviksin tamamen dilatasyonuna kadar geçen süreler ve fetal sonuçlar açısından kontrol grubu ile karşılaştırıldı.

Bulgular: Hafif, orta ve şiddetli ICP gruplarında PGE2'nin yerleştirilmesinin başlangıcından aktif evreye kadar geçen süre ICP olmayan gruptakine göre daha kısaydl; sırasıyla, $3,19 \pm 0,32,7,26 \pm 0,34,8,71 \pm 0,35$ saat $(p<0,01)$. Hafif, orta ve şiddetli ICP gruplarında PGE2'nin yerleştirilmesinin başlangıcından serviksin tamamen dilatasyonuna kadar geçen süre ICP olmayan gruptakine göre daha kısaydı; sırasıyla, 3,03 $\pm 0,45,10,33 \pm 0,62,14,44 \pm 0,53$ saat $(p<0,01)$. Gruplar arasında fetal ağırlık ve mekonyum varlığı dışında fetal sonuçlar açısından fark yoktu $(p<0,01)$.

Sonuç: Hafif, orta ve şiddetli ICP'de vajinal PGE2 ile indüklenen multipar gebe kadınlarda artan safra asidi konsantrasyonları, daha kısa servikal olgunlaşma süresi ve daha kısa doğum indüksiyon süresi ile ilişkilidir. Bu çalışma, ICP'li multipar gebelerin kolestazın şiddeti artııkça daha hızlı doğum yapabilecekleri sonucuna vardı.

Anahtar kelimeler: doğum süresi, gebeliğin intrahepatik kolestazı, kolestazın şiddeti, prostaglandin E2, safra asidi

\section{INTRODUCTION}

Intrahepatic cholestasis of pregnancy (ICP) is a liver disorder characterized by an increase in serum bile concentrations $(\geq 10 \mathrm{mmol} / \mathrm{L}$ ) in the third trimester with itching, and recovers rapidly during the postnatal period, but may recur in subsequent pregnancies [1]. It occurs with an incidence of 0.3-5.6\% of all pregnancies [2]. Although genetic, endocrine, and environmental factors have been implicated in the etiology, the underlying pathophysiology has not yet been elucidated [3].

ICP may result in maternal complications (preeclampsia, gestational diabetes mellitus, and postpartum hemorrhage) and fetal complications (prematurity, meconium staining, fetal distress, and sudden intrauterine death) [4]. In 1.2\% of pregnancies, women who still have ICP after the 37th gestational week may experience sudden intrauterine fetal loss and the risk increases proportionally as the gestational week and bile acid concentrations increase [5]. Serum bile acid concentrations $>40 \mu \mathrm{mol} / \mathrm{L}$ are associated with increased adverse pregnancy outcomes [6]. The bile acids are known to be cardio-myotoxic and may result in sudden intrauterine fetal loss due to either fetal cardiac arrhythmias or restriction of placental chorionic veins through a vasoconstrictive effect [7]. In addition, bile acids increase fetal bowel movements and may cause amniotic staining with meconium [8].
Vaginal delivery at 37 weeks gestation is recommended to prevent maternal and fetal morbidities and term stillbirth; however, there is still no consensus on the mode and timing of delivery [9]. According to a study, the most appropriate time for delivery to prevent fetal death without increasing the risk of fetal prematurity was the 36th gestational week [10]. Some pregnant women with ICP experience premature spontaneous delivery [11]. Increased bile acid levels induces myometrial contractility by increasing the susceptibility of endogenous oxytocin [12]. Preterm birth is more common in pregnant women with ICP, but increased serum bile acid concentrations does not change the duration of spontaneous deliveries [13]. We hypothesized that the severity of ICP might augment cervical ripening and shorten the first stage of labor via the vaginal route in multiparous women induced by vaginal prostaglandin E2 (PGE2) for starting labor.

The aim of this study was to show how increased severity of ICP affected the time from beginning of PGE2 vaginal insertion to active phase of labor, the time from beginning of PGE2 vaginal insertion to complete dilatation of cervix, the need for oxytocin induction, and neonatal outcomes in multiparous women induced by vaginal PGE2 with ICP.

\section{MATERIALS AND METHODS}

A total of 780 multiparous women who had delivered vaginally were enrolled in this retrospective case control study conducted between 2010 and 2018 in Maternity 
Hospital, Samsun, Turkey. Four hundred ninety-seven ICP files were pulled from the hospital archive and 122 files were excluded firstly, due to having cesarean delivery. As well as 92 files were excluded due to spontaneous deliveries. The remaining 123 multiparous women with mild ICP, 101 multiparous women with moderate ICP, 59 multiparous women with severe ICP who were hospitalized for delivery at 36-37 weeks' gestation through the use of vaginal PGE2 were included in the study. Two hundred and eighty-three healthy multiparous pregnant women with oligohydramnios in 36-37 weeks' gestation who were admitted for induction of delivery by vaginal PGE2, were included in the control group for comparisons. Pregnant women with preeclampsia, gestational diabetes mellitus, chronic diseases such as hypothyroidism, multiple pregnancies, polyhydramnios, presentation anomalies, fetal anomalies, and previous cesarean section were excluded from both groups. Ethics committee approval was obtained (TUEK 191-2018 GOKAEK/13-100).

ICP was defined as a clinical condition in pregnancy with serum bile acid concentrations $10 \mu \mathrm{mol} / \mathrm{L}$ and above, accompanied by pruritus. Serum bile acid concentrations in pregnant women with ICP were grouped as mild (10-19.9 $\mu \mathrm{mol} / \mathrm{L})$, moderate $(20-39.9 \mu \mathrm{mol} / \mathrm{L})$, and severe ICP (40 $\mu \mathrm{mol} / \mathrm{L}$ and above) [14]. Each pregnant woman with ICP started oral administration of urso-deoxycholic acid (UDCA) (10-15 mg/kg/day), and their bile acid concentrations were measured weekly as well as undergoing Doppler ultrasonography and non-stress tests (NST) [15].

In Samsun Maternity hospital, all women with ICP were delivered by induction of labor at 36-37 weeks' gestation according to the severity of the disease. Additionally, the decision for delivery was made immediately in patients with a serum bile acid concentration of $\geq 100 \mu \mathrm{mol} / \mathrm{L}$, in utero fetal death due to ICP before the 37th gestational week in previous pregnancy, deteriorated clinical and laboratory findings despite drug treatment in the 36th-37th gestational weeks after fetal pulmonary maturation.

Prostaglandin E2 (Propess ${ }^{\circledR}$, Ferring, Italy) (10 mg dinoprostone) was placed in the posterior vaginal fornix to ensure cervical maturation, withdrawn when cervical dilatation reached $4 \mathrm{~cm}$ and the effacement reached $60 \%$. Thus, uterine contractions reaching 200 Montevideo units per 20-minute period were achieved spontaneously. Twenty units oxytocin (Synpitan ${ }^{\circledR}$, Deva, Turkey) was administered to the patients with reduced contraction frequency or potency during their follow-up. Continuous external fetal monitoring and hourly maternal blood pressure follow-up were performed. Cesarean section was performed for indications such as fetal distress or labor arrest.

First stage of labor is the time from onset of labor to complete cervical dilation and it consists of a latent phase (gradual cervical change) and an active phase (rapid cervical change) [16]. The time to active phase which indicates successful labour induction, was calculated as the time from the beginning of PGE2 vaginal insertion to active phase of labor. The time to total cervical dilatation which was accepted as first stage of labor, was calculated as the time from the beginning of PGE2 vaginal insertion to total cervical dilatation.

Demographic information including age, gravidity, parity, abortion, gestational week for delivery; laboratory values including bile acid, aspartate aminotransferase (AST), alanine aminotransferase (ALT), and total bilirubin concentrations; and data on the time from beginning of PGE2 vaginal insertion to active phase of labor, the time from beginning of PGE2 vaginal insertion to complete dilatation of cervix, need for induction were collected from the hospital's archive records for both groups. We also collected data on fetal weight, $5^{\text {th }}$ Apgar score, umbilical cord arterial $\mathrm{pH}$ values, need for intubation, and the presence of meconium in amnion fluid.

Pregnancy weeks were calculated according to the last menstrual period. First trimester ultrasound recordings used for those who did not know their last menstrual period. According to the data we inspected retrospectively, fasting serum bile acid concentrations had been evaluated using, a Cobas 6000-C501 analyzer (Roche, Indianapolis, IN, USA), and AST, ALT, and total bilirubin levels had been evaluated using an AU5800 clinical chemistry analyzer (Beckman Coulter, Brea, CA, USA).

Statistical analysis: The study data were statistically analyzed using IBM SPSS Statistics 21.0 (IBM Corp. Armonk, NY). Descriptive data were expressed in means \pm standard deviations and median (minimum-maximum). Oneway ANOVA Test and Kruskal Wallis Test were used to compare three or more groups. Bonferroni Test was used as a subgroup analysis to find out which group caused the significant difference. Chi-square test was used for the analysis of categorical variables. $P$ value $<0.05$ was considered statistically significant. For subgroup analysis $P$ value $<0.008$ was considered statistically significant.

\section{RESULTS}

A total of 566 women met criteria for inclusion in this study, 283 in the control group and 283 in the ICP case group. The 
Şahin et al. / The severity of intrahepatic cholestasis of pregnancy can shorten the labor

Table 1. Evaluation of demographic characteristics, pregnancy induction characteristics and laboratory results of pregnant women according to severity of ICP

\begin{tabular}{|c|c|c|c|c|c|}
\hline & Control $(n=283)$ & Mild $(n=123)$ & Moderate $(n=101)$ & Severe $(n=59)$ & P value \\
\hline Age (year) & $26.40 \pm 4.59$ & $27.67 \pm 5.15$ & $26.90 \pm 4.90$ & $26.02 \pm 3.54$ & 0.051 \\
\hline Gravidity & $3(2-6)$ & $3(1-5)$ & $3(2-5)$ & $3(2-6)$ & 0.052 \\
\hline Parity & $1(1-3)$ & $1(1-3)$ & $1(1-4)$ & $1(1-4)$ & 0.467 \\
\hline Abortion & $0(0-4)$ & $1(0-2)$ & $1(0-2)$ & $0(0-2)$ & 0.071 \\
\hline Gestational week & $36.90 \pm 0.29$ & $36.90 \pm 0.29$ & $36.84 \pm 0.36$ & $36.81 \pm 0.39$ & 0.186 \\
\hline Bile acid $(\mu \mathrm{mol} / \mathrm{L})$ & $0^{\mathrm{a}}$ & $16.29 \pm 2.72^{\mathrm{b}}$ & $31.17 \pm 6.33^{c}$ & $73.82 \pm 39.47^{d}$ & $<0.001^{*}$ \\
\hline AST (IU/L) & $22.57 \pm 8.99^{\mathrm{a}}$ & $42.95 \pm 19.57^{b}$ & $66.51 \pm 48.29^{c}$ & $107.03 \pm 65.82^{d}$ & $<0.001^{*}$ \\
\hline ALT (IU/L) & $21.92 \pm 9.00^{\mathrm{a}}$ & $41.83 \pm 19.86^{b}$ & $70.20 \pm 59.70^{c}$ & $106.42 \pm 69.99^{d}$ & $<0.001^{*}$ \\
\hline Total bilurubin (mg/dL) & $1.08 \pm 0.32^{\mathrm{a}}$ & $1.10 \pm 0.15^{b}$ & $1.08 \pm 0.22^{\mathrm{ac}}$ & $1.19 \pm 0.22^{\mathrm{bd}}$ & $0.034^{*}$ \\
\hline
\end{tabular}

$\mathrm{ICP}=$ intrahepatic cholestasis of pregnancy, AST=aspartate aminotransferase, ALT=alanine aminotransferase. a-d: There is no difference between groups labeled under the same letter. Data presented as mean \pm standard deviation and median (minimum-maximum).

Table 2. Evaluation of labor and neonatal characteristics of pregnant women according to severity of ICP

\begin{tabular}{|l|c|c|c|c|c|}
\hline & Control $(\mathbf{n}=\mathbf{2 8 3})$ & Mild $(\mathbf{n = 1 2 3})$ & Moderate $(\mathbf{n = 1 0 1})$ & Severe $(\mathbf{n}=\mathbf{5 9})$ & P value \\
\hline Time to active phase $(\mathrm{h})$ & $17.12 \pm 3.81^{\mathrm{a}}$ & $13.93 \pm 2.50^{\mathrm{b}}$ & $9.86 \pm 2.54^{\mathrm{c}}$ & $8.41 \pm 2.05^{\mathrm{cd}}$ & $<0.001^{*}$ \\
\hline $\begin{array}{l}\text { Time to complete dilatation } \\
\text { of cervix }(\mathrm{h})\end{array}$ & $28.33 \pm 5.42^{\mathrm{a}}$ & $25.29 \pm 3.51^{\mathrm{b}}$ & $17.99 \pm 5.43^{\mathrm{c}}$ & $13.88 \pm 3.24^{\mathrm{d}}$ & $<0.001^{*}$ \\
\hline Induction & $216(76.3 \%)^{\mathrm{a}}$ & $72(58.5 \%)^{\mathrm{b}}$ & $43(42.6 \%)^{\mathrm{c}}$ & $16(27.1 \%)^{\mathrm{d}}$ & $<0.001^{*}$ \\
\hline Fetal weight (gr) & $3019.28 \pm 135.68^{\mathrm{a}}$ & $2793.01 \pm 174.53^{\mathrm{b}}$ & $2728.71 \pm 166.90^{\mathrm{bc}}$ & $2623.73 \pm 176.90^{\mathrm{d}}$ & $<0.001^{*}$ \\
\hline Fetal pH & $7.32 \pm 0.09$ & $7.34 \pm 0.09$ & $7.33 \pm 0.12$ & $7.31 \pm 0.12$ & 0.200 \\
\hline Intubation & $26(9.2 \%)$ & $10(8.1 \%)$ & $14(13.9 \%)$ & $11(18.6 \%)$ & 0.092 \\
\hline Meconium & $21(7.4 \%)^{\mathrm{a}}$ & $10(8.1 \%)^{\mathrm{ab}}$ & $22(21.8 \%)^{\mathrm{c}}$ & $15(25.4 \%)^{\mathrm{cd}}$ & $<0.001^{*}$ \\
\hline
\end{tabular}

ICP=intrahepatic cholestasis of pregnancy. One-Way ANOVA and Chi-square were used for comparisons of parameters. a-d: There is no difference between groups labeled under the same letter. Data presented as mean \pm standard deviation and $\mathrm{n}(\%)$

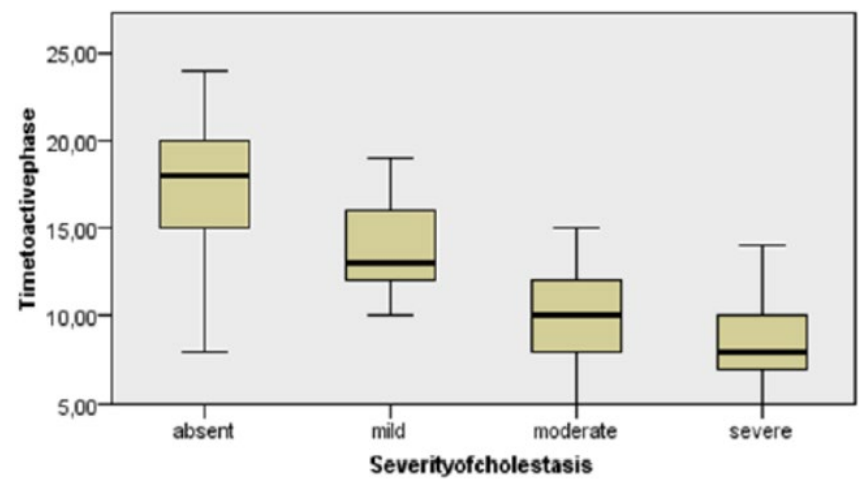

Figure 1. The time from beginning of PGE2 vaginal insertion to active phase of labor according to severity of ICP groups

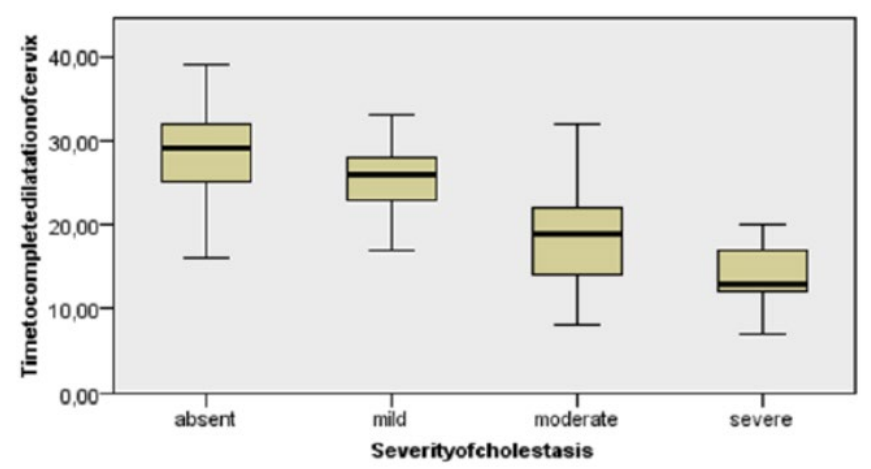

Figure 2. The time from beginning of PGE2 vaginal insertion to complete dilatation of cervix according to severity of ICP groups
Bile acid concentrations of the patients with ICP ranged from $10.3 \mu \mathrm{mol} / \mathrm{L}$ to $281 \mu \mathrm{mol} / \mathrm{L}$. In the ICP case group, $123 \mathrm{met}$ criteria for mild ICP (43\%), 101 moderate (36\%), and 59 severe (21\%). The evaluation of demographic characteristics and laboratory results of pregnant women with and without ICP is presented in Table 1.

The evaluation of labor and neonatal characteristics of pregnant women with and without ICP is presented in Table 2.

The time from beginning of PGE2 vaginal insertion to active phase in the mild, moderate and severe ICP groups were shorter than in the non-ICP group, respectively $3.19 \pm 0.32$, $7.26 \pm 0.34,8.71 \pm 0.35$ hours $(p<0.001)$ (Figure 1). The time from beginning of PGE2 vaginal insertion to complete dilatation of cervix in the groups with mild, moderate and severe ICP were shorter than in non-ICP group, respectively $3,03 \pm 0,45 ; 10,33 \pm 0,62 ; 14,44 \pm 0,53$ ( $p<0.001$ ) (Figure 2). The need for induction in the groups was decreased with increased levels of ICP $(p<0.001)$. There was no difference between the groups in terms of fetal outcomes except fetal weight and the presence of meconium $(p<0.001)$. The presence of meconium in amnion in the groups was correlated with increased levels of ICP $(p<0.001)$. 


\section{DISCUSSION}

This is the first evaluation to compare the first stage of labor in multiparous women induced by vaginal PGE2 with mild, moderate, severe ICP, and no ICP. It was observed that as the bile acid concentration increased, the effect of vaginal PGE2 was augmented and the need for induction was reduced. Thus, the time from beginning of vaginal PGE2 insertion to active phase of labor and the time from beginning of vaginal PGE2 insertion to complete dilatation of cervix were reduced.

In clinical practice, spontaneous and iatrogenic preterm deliveries occur as the bile acid concentration increases in pregnant women with ICP, and negative fetal consequences may be experienced [17]. There is still no consensus on the gestational week for delivery of pregnancy with ICP due to the need for NICU, which may be associated with premature birth, and the risk of stillbirth because of late birth decision. Even though women with ICP use UDCA regularly to decrease bile acid concentrations, albeit rare, they may still experience stillbirths, when birth decision is taken after the 37th gestational week [18]. In particular, if the serum bile acid concentration exceeds $100 \mu \mathrm{mol} / \mathrm{L}$, the birth decision may be taken as early as the 34th gestational week [15]. In our ICP groups the mean gestational week for induction by vaginal PGE2 were $36^{\text {th }}$.

Increased serum bile acid concentrations in women with ICP is known to cause spontaneous preterm birth by increasing myometrial activity and oxytocin sensitivity [19]. In this study, based on the hypothesis that pregnant women with ICP delivered faster than those without ICP, it was predicted that bile acids would accelerate cervical maturation, and this would naturally accelerate the stages of labor. The PGE2, which was placed in the posterior fornix of vagina for inducing labor in pregnant women with ICP, provided faster cervical augmentation and regular uterine contractions. In patients with ICP, cervical ripening was more than seven hours faster than in those without ICP. It was observed that the cervical maturation of patients with a serum bile acid concentration $>20 \mu \mathrm{mol} / \mathrm{L}$ was completed in 10 hours. In the literature, there are no studies that examined the effects of bile acids on cervical maturation. This is the first study on increased serum bile acids augmenting cervical maturation.

Bile acids increases the sensitivity of oxytocin in myometrial cells, and even colic acid produced myometrial contractions by increasing mRNA and protein levels at oxytocin receptor in vitro [12]. The mean time from beginning of vaginal PGE2 insertion to complete dilatation of cervix in women with ICP was ten hours shorter than in women without ICP. In the ICP group, as the serum bile acid concentration increased, the mean time from beginning of vaginal PGE2 insertion to total cervical dilatation decreased dramatically. In fact, those with a serum bile acid concentration $\geq 40 \mu \mathrm{mol} / \mathrm{L}$ had active birth pain after as little as five hours on average. When the time from beginning of vaginal PGE2 insertion to active phase of labor was shortened, the time from beginning of vaginal PGE2 insertion to complete dilatation of cervix was also shortened. Therefore, as the serum bile acid concentrations increased, the time from beginning of vaginal PGE2 insertion to complete dilatation of cervix was shortened. The mean time from beginning of vaginal PGE2 insertion to complete dilatation of cervix fell below 18 hours in women with a serum bile acid concentration $\geq 20 \mu \mathrm{mol} / \mathrm{L}$.

Serum bile acid concentrations over $40 \mu \mathrm{mol} / \mathrm{L}$ as high-risk pregnancy with ICP; no difference is observed in modes of delivery of pregnancies that are terminated at the 37 th gestational week [20]. In a retrospective study, there was no increase in intervention delivery or cesarean delivery rates in women with ICP [21]. Also, no difference was observed in terms of the first and second stage of the delivery periods of pregnant women with ICP compared with the control group. It was found that the rate of emergency cesarean sections in women with and without ICP whose deliveries began spontaneously were similar [22]. However, pregnant women with ICP whose labor was induced by oxytocin, required emergency cesarean sections less frequently. It was reported that bile acids, which increase uterine contractility, reduce the delivery duration and the need for emergency cesarean section by removing the possible fetal distress [22]. The need for urgent cesarean section was detected as $24.5 \%$ in multiparous pregnant women with ICP who had vaginal delivery previously, in our study. A serum bile acid concentration of $\geq 10 \mu \mathrm{mol} / \mathrm{L}$ accelerates the delivery period and reduces the risk of fetal distress and the need for emergency cesarean section.

Meconium staining is more frequent in infants with a maternal bile acid concentration $\geq 40 \mu \mathrm{mol} / \mathrm{L}$ [23]. Although severe ICP allows delivery without creating fetal distress by shortening the delivery duration, high concentrations of bile acids affect fetal colonic activity directly in the early weeks of pregnancy, resulting in the presence of meconium in amnion fluid [24]. A possible correlation of amnion staining with meconium was detected for a bile acid concentration $\geq 20 \mu \mathrm{mol} / \mathrm{L}$ in the present study.

Retrospective nature and comparing ICP patients with oligohydroamnios pregnancy patients are major flaws in this study. Failure to prevent fetal deaths despite close fetal 
examination using ultrasound and cardiotactography prevents obstetricians from performing prospective studies in ICP. Currently, there is no guideline describing the optimal time to initiate delivery in ICP. It is generally emphasized in these guidelines that the decision to give birth can be made according to the clinical presentation of pregnant women and fetal well-being [25].

In conclusion, pregnant women with ICP and serum bile acid concentrations of $10 \mu \mathrm{mol} / \mathrm{L}$ and above did not generally have negative maternal and fetal outcomes in delivery at the 36 th gestational week. PGE2 affected cervical ripening faster as serum bile acid concentrations increased. Thus, deliveries started faster and the first stage of labor were shortened in women with ICP, induced by vaginal PGE2.

\section{ACKNOWLEDGEMENTS}

Authors would like to thank David Chapman from Pure Medical Editing for editing of the manuscript.

\section{DECLARATION OF CONFLICT OF INTEREST}

The authors received no financial support for the research and/or authorship of this article. There is no conflict of interest.

\section{REFERENCES}

1. Williamson C, Geenes V. Intrahepatic cholestasis of pregnancy. Obstetrics and Gynecology 2014; 124: 12033. (doi: 10.1097/AOG.0000000000000346).

2. Bicocca MJ, Sperling JD, Chauhan SP. Intrahepatic cholestasis of pregnancy: Review of six national and regional guidelines. European Journal of Obstetrics and Gynecology and Reproductive Biology 2018; 231: 180-7. (doi: 10.1016/j.ejogrb.2018.10.041).

3. Than NN, Neuberger J. Liver abnormalities in pregnancy. Best Practice and Research: Clinical Gastroenterology 2013; 27: 565-75. (doi: 10.1016/j.bpg.2013.06.015).

4. Brouwers L, Koster MP, Page-Christiaens GC, et al. Intrahepatic cholestasis of pregnancy: maternal and fetal outcomes associated with elevated bile acid levels. American Journal of Obstetrics and Gynecology 2015; 212: 1-7. (doi: 10.1016/j.ajog.2014.07.026).

5. Bacak SJ, Olson-Chen C, Pressman E. Timing of induction of labor. Seminars in Perinatology 2015; 39: 450-8. (doi: 10.1053/j.semperi.2015.07.007).
6. Geenes V, Chappell LC, Seed PT, et al. Association of severe intrahepatic cholestasis of pregnancy with adverse pregnancy outcomes: a prospective populationbased case-control study. Hepatology 2014; 59: 1482-91. (doi: 10.1002/hep.26617).

7. Diken Z, Usta IM, Nassar AH. A clinical approach to intrahepatic cholestasis of pregnancy. American Journal of Perinatology 2014; 31: 1-8. (doi: 10.1055/s-00331333673).

8. Glantz A, Marschall HU, Mattsson LA. Intrahepatic cholestasis of pregnancy: Relationships between bile acid levels and fetal complication rates. Hepatology 2004; 40: 467-74. (doi: 10.1002/hep.20336).

9. Tran TT, Ahn J, Reau NS. ACG clinical guideline: liver disease and pregnancy. The American Journal of Gastroenterology 2016; 111: 176-94. (doi: 10.1038/ajg.2016.462).

10. Lo JO, Shaffer BL, Allen AJ, et al. Intrahepatic cholestasis of pregnancy and timing of delivery. Journal of MaternalFetal and Neonatal Medicine 2015; 28: 2254-8. (doi: 10.3109/14767058.2014.984605).

11. Marathe JA, Lim WH, Metz MP, et al. A retrospective cohort review of intrahepatic cholestasis of pregnancy in a South Australian population. European Journal of Obstetrics and Gynecology and Reproductive Biology 2017; 218: 33-8. (doi: 10.1016/j.ejogrb.2017.09.012).

12. Germain AM, Kato S, Carvajal JA, et al. Bile acids increase response and expression of human myometrial oxytocin receptor. American Journal of Obstetrics and Gynecology 2003; 189: 577-82. (doi: 10.1067/S00029378(03)00545-3).

13. Sharifzadehgan S, Hermann M, Nedellec $S$, et al. Intrahepatic cholestasis of pregnancy: Shorter duration of labor? European Journal of Obstetrics and Gynecology and Reproductive Biology 2018; 225: 258-9. (doi: 10.1016/j.ejogrb.2018.03.045).

14. Estiú MC, Frailuna MA, Otero C, et al. Relationship between early onset severe intrahepatic cholestasis of pregnancy and higher risk of meconium-stained fluid. PLoS One 2017; 12: e0176504. (doi: 10.1371/journal.pone.0176504). 
15. Chappell LC, Gurung V, Seed PT, et al. PITCH Study Consortium. Ursodeoxycholic acid versus placebo, and early term delivery versus expectant management, in women with intrahepatic cholestasis of pregnancy: semifactorial randomised clinical trial. British Medical Journal 2012; 344: 3799. (doi: 10.1136/bmj.e3799).

16. Zhang J, Troendle J, Mikolajczyk R, et al. The natural history of the normal first stage of labor. Obstet Gynecol 2010; 115: 705. (doi: 10.1097/AOG.0b013e3181d55925).

17. Wikstron Shemer E, Marschall HU, Ludvigsson J, et al. Intrahepatic cholestasis of pregnancy and associated adverse pregnancy and fetal outcomes: a 12- year population-based cohort study. BJOG 2013; 120: 717-23. (doi: 10.1111/1471-0528.12174).

18. Puljic A, Kim E, Page J, et al. The risk of infant and fetal death by each additional week of expectant management in intrahepatic cholestasis of pregnancy by gestational age. American Journal of Obstetrics and Gynecology 2015; 212: 667: 1-5. (doi: 10.1016/j.ajog.2015.02.012).

19. Zhao P, Zhang K, Yao Q, et al. Uterine contractility in intrahepatic cholestasis of pregnancy. Journal of Obstetrics and Gynaecology 2014; 34: 221-4. (doi: 10.3109/01443615.2013.834878).

20. Friberg AK, Zingmark V, Lyndrup J. Early induction of labor in high-risk intrahepatic cholestasis of pregnancy: what are the costs? Archives of Gynecology and Obstetrics 2016; 294: 709-14. (doi: 10.1007/s00404-0164019-8).
21. Webster JR, Chappell L, Cheng F, et al. Operative delivery rates following induction of labour for obstetric cholestasis. Obstetric Medicine 2011; 4: 66-9. (doi: 10.1258/om.2011.110080).

22. Wikström Shemer EA, Thorsell M, Marschall HU, et al. Risks of emergency cesarean section and fetal asphyxia after induction of labor in intrahepatic cholestasis of pregnancy: a hospital-based retrospective cohort study. Sexual and Reproductive HealthCare 2013; 4: 17-22. (doi: 10.1016/j.srhc.2012.11.005).

23. Cui D, Zhong $Y$, Zhang $L$, et al. Bile acid levels and risk of adverse perinatal outcomes in intrahepatic cholestasis of pregnancy: A meta-analysis. Journal of Obstetrics and Gynaecology Research 2017; 43: 1411-20. (doi: 10.1111/jog.13399).

24. Kawakita T, Parikh LI, Ramsey PS, et al. Predictors of adverse neonatal outcomes in intrahepatic cholestasis of pregnancy. American Journal of Obstetrics and Gynecology 2015; 213: 5701-8. (doi: 10.1016/j.ajog.2015.06.021).

25. Arthur C, Mahomed K. Intrahepatic cholestasis of pregnancy: diagnosis and management; a survey of Royal Australian and New Zealand College of Obstetrics and Gynaecology fellows. Australian and New Zealand Journal of Obstetrics and Gynaecology 2014; 54: 263-7. (doi: 10.1111/ajo.12178). 